\title{
Contribution to the morphometric characterization and physico-chemical analysis of meat of porcupines (Hystrix cristata) in Tlemcen region
}

\author{
Boufatah SM. ${ }^{1}$ Mkedder I. ${ }^{1,2}$ Gaouar S.B.S. ${ }^{1,2}$.
1:Physiopathology and nutritional biology laboratory(PpBioNut), University of Abu Bekr Belkaid, Tlemcen, Algeria \\ 2: Genetics applied in agronomy, ecology and public health (GenApAgiE), University of Abu Bekr Belkaid, \\ Tlemcen
}

\begin{abstract}
*Corresponding Author: Sidi Mohamed Boufatah, University of Abu Bekr Belkaid, Tlemcen, Algeria Email: boufatahmohamed2017@gmail.com; ikram13mk@gmail.com
\end{abstract}

Article history: Received: August 7th 2021; revised. September 25th 2021; accepted December 11th 2021

\begin{abstract}
In Algeria, the work undertaken on the ecology of wild rodents mainly focuses on gerbils and merions, and Cténdactylideae. As for hystricide, to our knowledge studies are non-existent although porcupine (Hystrix cristata). Although being a protected species, the porcupine is considered an agricultural pest, with tasty meat, and therefore largely poached. This study took place over a two-year cycle from 2017 to 2019. Field investigations began in region of Tlemcen. A survey was carried out to collect information; we used 25 questions about farmer and hunter like age, jobs, profession ...) also a question about the use of porcupine in this area and how the farmer and hunter deal with this animal. Sampling was carried out on individuals of both sexes, male and female. A tot al of 22 individuals were sampled, including 12 males and 10 females. The description of the qualitative characteristics was made using a visual examination. Two qualitative variables were studied. The description of the quantitative characteristics was ca rried out using a tape measure in which each animal was subjected to 15 body measurements. For the physico -chemical analysis, $100 \mathrm{~g}$ of fresh meat from two healthy individuals was used. Descriptive analysis revealed that females are larger than males; the black color of the skin is the most dominant compared to the dark brown and light brown color. Principal component analysis (PCA) has shown that all quantitative variables are positively correlated with each other. The principal component analysis of individuals by region shows that the majority of individuals from the interior plains have high values (Maghnia and Remchi) and the majority of individuals from forest areas have the lowest values (Ghazawat, Mafrouche and Ain fezza) . Principal component analysis of individuals by sex shows that females contain high values compared to males. Principal component analysis of individuals by skin color shows no difference between individuals. The ascending hierarchical classification (CAH) confirmed the results of th e CPA which allowed us to distinguish 4 classes. The results of physico-chemical analysis of the fresh meat of 2 individuals (male and female) of the Ghanmi breed, for $100 \mathrm{~g}$ of fresh meat reveal that the protein content is $21.5-20 \mathrm{~g}$, the lipid content is quite important in the female compared to the male. In contrast, the carbohydrate content and per $100 \mathrm{~g}$ of meat was zero.

Key words: porcupines, morphometric, physico-chemical, characterization, Algeria
\end{abstract}

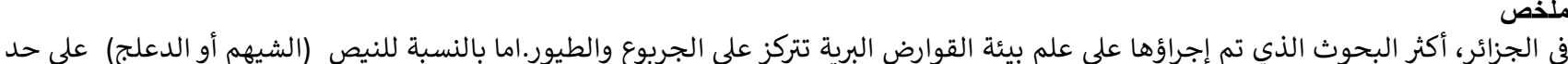

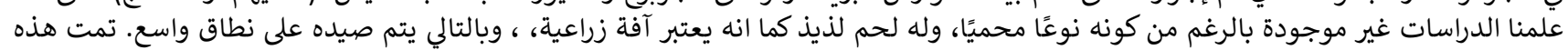

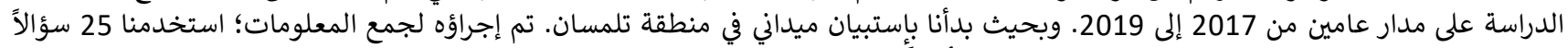

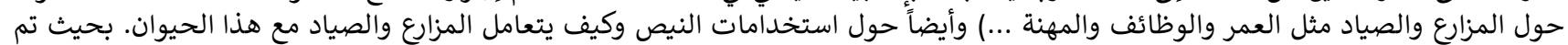

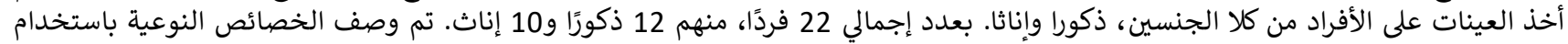

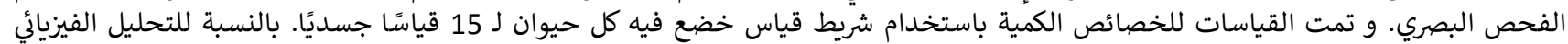

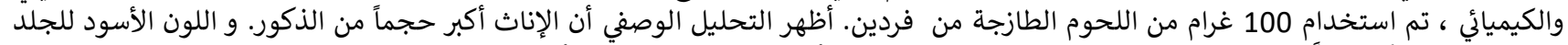

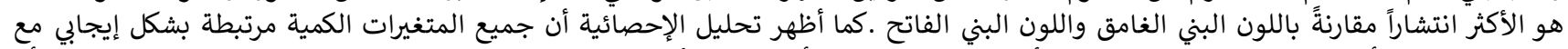

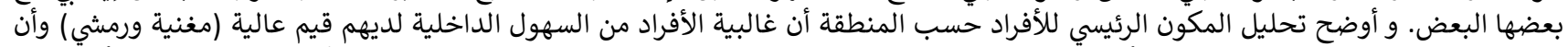

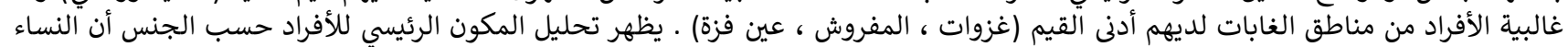

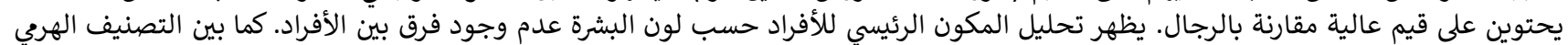

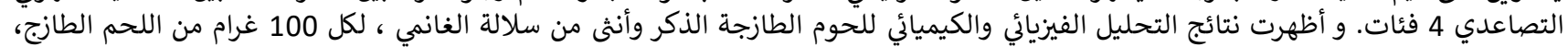

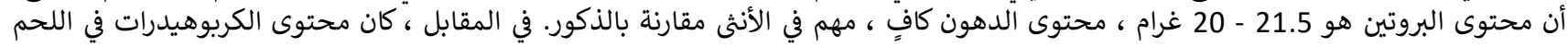

$$
\text { الكلمات المفتاحية: النيص. وصف. للتحليل الفيزيائي والكيميائي. الجزائر. }
$$




\section{Introduction}

Northwest Africa is one of the regions that deserves to be investigated by ecological research because on the one hand, it constitutes a biogeographic crossroads between the Palearctic and Afro-tropical regions (Olson et al, 2001) and on the other hand, it belongs to the Mediterranean region, one of the most important biodiversity hotspots in the world (Myerset al, 2000). Indeed, Algeria currently has 108 species of mammal (Stork and Samways, 1995; Abdelguerfi et al, 2009).

However, Cited by Yaa Ntiamoa-Baidu, 1987, in Africa, overexploitation threatens to destroy wildlife in many places, which is both an important traditional source of food and income and a cultural value. The Algerian mammalian population is unfortunately no exception to these threatsIn Algeria, the work undertaken on the ecology of wild rodents is focused mainly on gerbilids and meriones (Bela Bbas, et al, 1994; Adamou-Djerbaoui, 2012) , and the Cténdactylideae (Gouat and Gouat, 1982, 1983, 1985, 1987, 1988).

As for the Hystricid, to our knowledge studies are non-existent although the porcupine (Hystrix cristata) is cited by several authors (such as Koenen F, 1999, Lin W, 2012 and Giusy C, 2016). This animal is a rodent that is part of the list of non-domestic animal species protected by Decree No. 83/509 of 20 August 1983 on protected non-domestic wildlife, supplemented by Executive Decree No. 12-235 of 3 Rajab 1433 corresponding to 24 May 2012. Despite being a protected species, the porcupine is considered as an agricultural pest, with tasty meat, so widely poached (Sandro L et al, 2017).

Cited by Banfield, 1977, porcupine frequents a range of vegetation areas in North America, from semi-desert to tundra. Porcupines are also found in Africa and Asia, but these do not belong to the same family as the Porcupines of the New World.

With a view to the conservation of protected species, in particular this rodent. The prior collection of information is necessary. Our work therefore focused on the description of this animal at the level of the Tlemcen region. This study concern a morpho-biometric description of porcupine (Hystrix cristata) and physicochemical analysis of its meat.

\section{Materials and methods}

\section{Experimental Site}

This study took place over a two-year cycle from 2017 to 2019. Field investigations have begun in the Tlemcen willaya (Figure 1). The latter occupies a position of choice within the national whole, wilaya has both border and obliteral, constituting a small inclusion in the north of the wilaya of naàma which is the continuity of the steppe part of the wilaya of Tlemcen. It is a region located geographically in the extreme west of Algeria at $1^{\circ} 27^{\circ}$ and $1^{\circ} 51^{\circ}$ west longitude and at $34^{\circ} 27^{\circ}$ and $35^{\circ} 18^{\circ}$ north latitude. It is bounded by the Mediterranean Sea to the north, the wilaya of Naàma to the south, the Algeco-Moroccan border to the west, the wilaya of sidi Babel abbots to the southeast and the wilaya of Ain timouchant to the northeast. The wilaya of Tlemcen covers an area of $9017.69 \mathrm{~km}$. From the coast to the north to the steppe to the south constituting aisi a landscape diversifies or meets it four distinct physical ensembles. This heterogeneity of relief begins with:The chain of the Traras mountains and the Sebaachionkh mountains whose altitude varies between 500 and $1000 \mathrm{M}$.

- The sublittoral plains represented by the basin of Tlemcen and the low valées of the Tafna and lsser, and the plateaus of Ouled Riah being located 200 and $400 \mathrm{M}$ of altitude.

- The mountains of Tlemcen which stand as a real natural barrier between the seppe and the tell, and culminate at $1845 \mathrm{~m}$ at the Jebel Tenouchifi (Sidi Djilali) and not exceeding the $20 \mathrm{KM}$ wide.

- All the high steppe plains are wide of about $100 \mathrm{KM}$ and an altitude of $1100 \mathrm{M}$ on average.

\section{Field prosperction}

Field prospecting was done in Tlemcen region with farmers and hunters of the region, aiming not only to have a sampling of individuals for morpho-metric characterization, but also to define the environment and dispersion of porcupine in the region study (the range). Traps have also been set up for catching animals. During all our outings we took with us a tape put and a camera. 


\section{Morpho-Biometric study}

a survey has been released in this study to hunter, 25 questions were asked about, their age, education level , the field of work, occupations ..ect and there was questions about the use and breeding of porcupine, in the region of study and how farmer and hunters treat this animal.(veiw the appendice 1).

the sampling of animals in the state of Tlemcen ( table 01) is in objective to study the morphometric characteristics of the population of porc-epic ( Hystrix cristata) in collaboration with farmers and hunters . however the selection of hunting areas was through Animals footprints and droppings ( Figure 02)

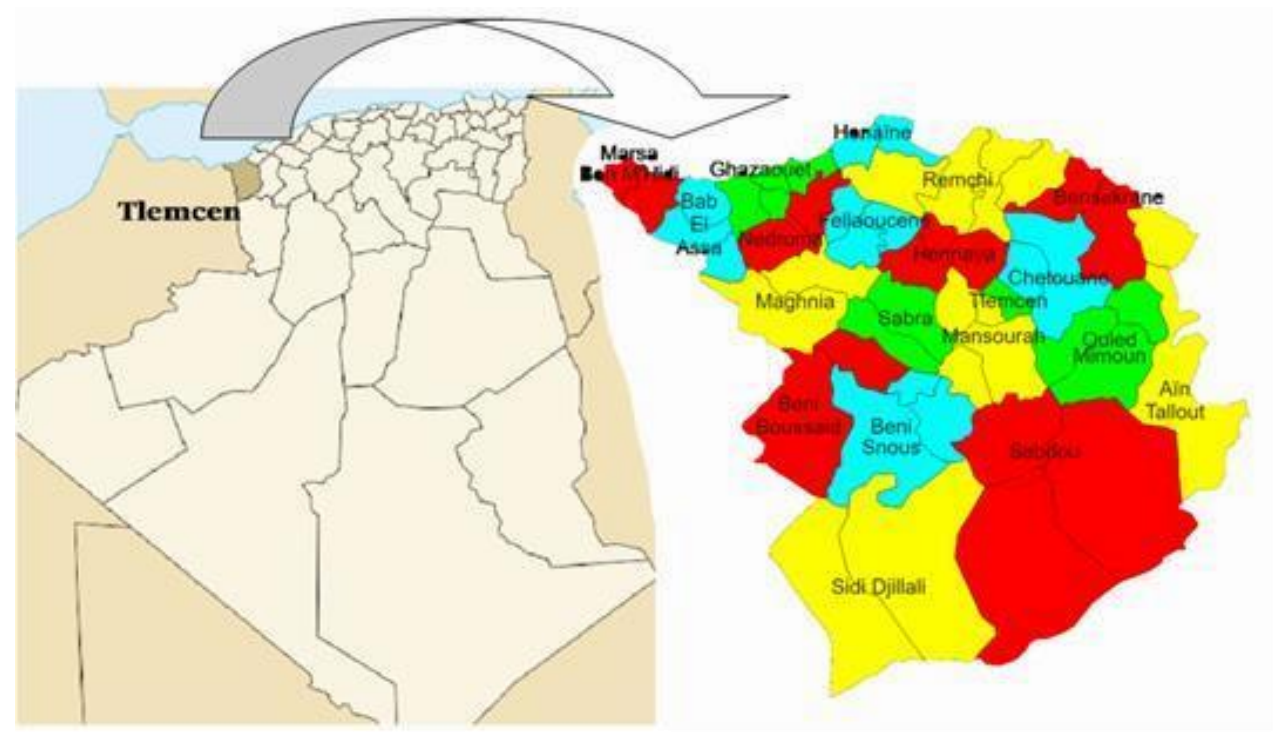

Figure 1: study zone

Table 1: Geographical Location of Study Areas

\begin{tabular}{ll}
\hline Region & Geographical Location \\
\hline Maghnya & $34^{\circ} 51^{\prime} 42^{\prime \prime}$ North, $1^{\circ} 43^{\prime} 50^{\prime \prime}$ West \\
Ghazaouet & $35^{\circ} 05^{\prime} 38^{\prime \prime}$ North, $1^{\circ} 51^{\prime} 37^{\prime \prime}$ West \\
Remchi & $35^{\circ} 03^{\prime} 00^{\prime \prime}$ North, $1^{\circ} 26^{\prime} 00^{\prime \prime}$ West \\
Ain Fezza & $34^{\circ} 52^{\prime} 38^{\prime \prime}$ North, $1^{\circ} 14^{\prime} 07^{\prime \prime}$ West \\
Mafrouche & $34^{\circ} 47^{\prime} 45^{\prime \prime}$ North, $1^{\circ} 21^{\prime 2} 29^{\prime \prime}$ West \\
\hline
\end{tabular}
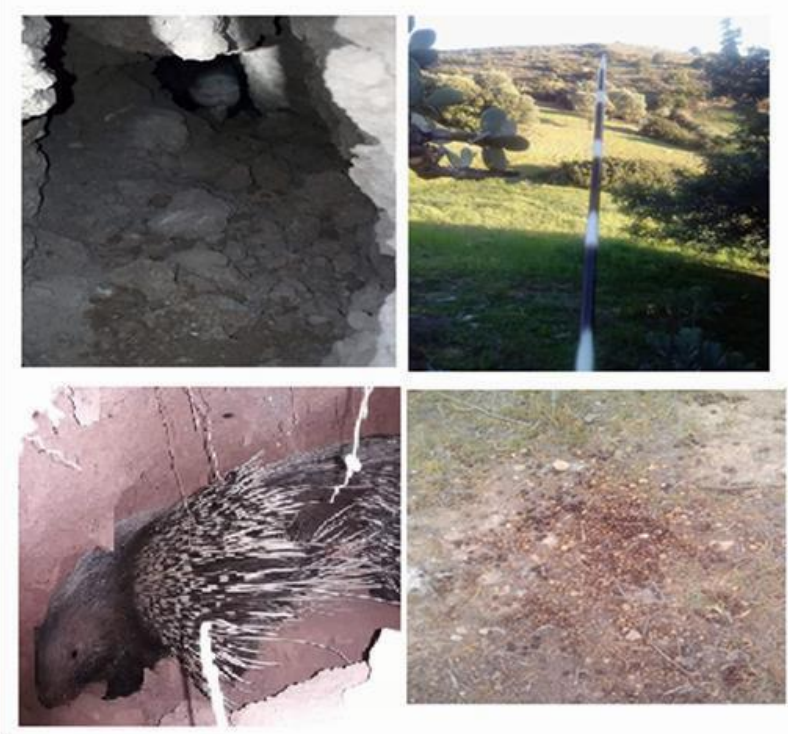

Figure 2: Traces of the animal (Tlemcen 2018) 
Sampling was done on individuals of both sexes, male and female. A total of 22 individuals were sampled including 12 males and 10 females as shown in Table 2.
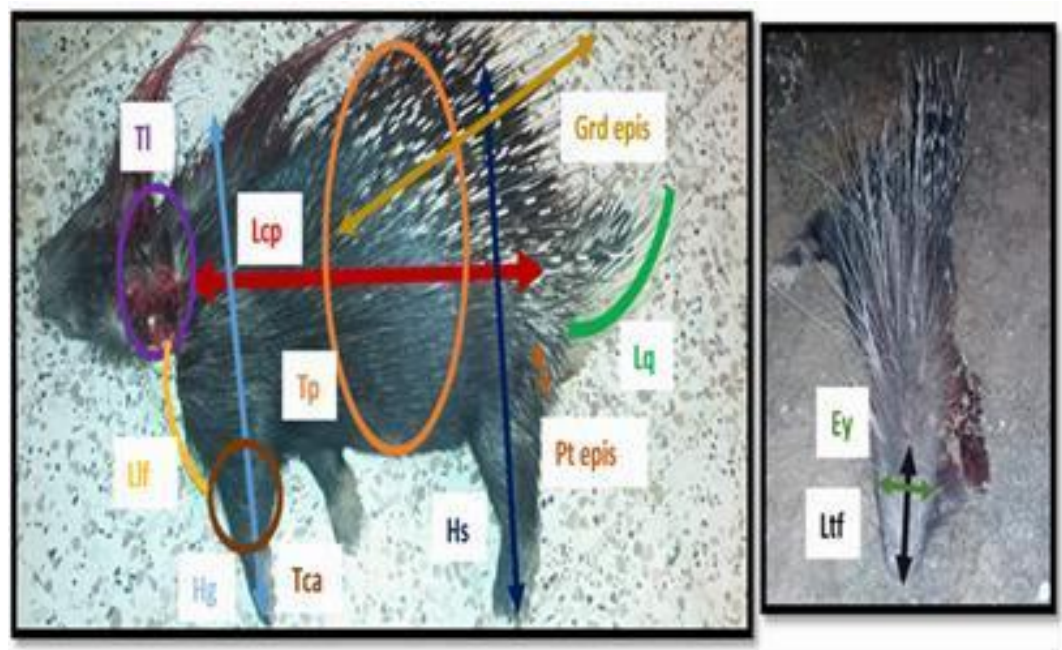

Figure 3: Representation of quantitative variables (Mafrouche, 2019)

Table 2: Distribution of the number of individuals by sex

\begin{tabular}{ll}
\hline Sexes & Number of individuals \\
\hline Males & 12 \\
\hline Females & 10 \\
\hline
\end{tabular}

The description of the qualitative characteristics was made using visual examination. Two qualitative variables were studied (Table 3):

Table 3: Qualitative variables studied

\begin{tabular}{lll}
\hline character & Abbreviation & Modality \\
\hline $\operatorname{sex}$ & sex & $1=$ male; $2=$ female \\
\hline \multirow{2}{*}{ Color of the dress } & CR & $\frac{1=\text { light brown MC }}{2=\text { brown darken }(\mathrm{MF})}$ \\
& & $3=$ black(N) \\
\hline
\end{tabular}

The description of the quantitative characteristics was carried out using a tape measure, each animal of which was subjected to 15 body measurements (Figure 03) defined at the table 4.

The data processing was carried out by software R (3.5.1). Before starting the statistical tests, a normality test on the data of the different characters was carried out with the "Feather Spray" test. A descriptive analysis of the qualitative and quantitative variables as well as the correlation between the quantitative variables (Pearson test) was understood. The multivariate analysis was performed via the principal component analysis, hierarchical bottom-up classification and Mahalanobis distance.

\section{Physico-chemical analysis of meat}

The physico-chemical study was carried out for 2 individuals (male and female) of the Ghanmi breed, (Figure 4 and Table 5) at a private quality analysis laboratory approved by the state (Karaouzen)

Table 5: individuals sampled for meat analysis

\begin{tabular}{ll}
\hline sex & Weight $\mathbf{~ K g})$ \\
\hline female & $24.5 \mathrm{Kg}$ \\
\hline Male & $22.5 \mathrm{Kg}$ \\
\hline
\end{tabular}


Table 4: Quantitative variables (definition)

\begin{tabular}{|c|c|c|}
\hline measure & abbreviation & principle \\
\hline Body length & lcp & $\begin{array}{l}\text { The horizontal distance from the tip of the shoulder to the } \\
\text { ischion }\end{array}$ \\
\hline Height at withers & hg & $\begin{array}{l}\text { The waist from the lower part of the front foot to the highest } \\
\text { point of the shoulder on the withers. }\end{array}$ \\
\hline Height at the sacrum & Broken & Distance from sacrum to ground \\
\hline Chest circumference & $\mathrm{Tp}$ & $\begin{array}{l}\text { The circumference of the body behind the scapula in a vertica } \\
\text { plane, perpendicular to the longitudinal axis of the body. }\end{array}$ \\
\hline Tower of the previous gun & tca & Tower of the front foot gun \\
\hline Tail length & LQ & Distance from tail attachment point to endpoint \\
\hline Neckline Tower & $\mathrm{tl}$ & The full circumference of the neck circumference \\
\hline Front neckline length & LLF & $\begin{array}{l}\text { Distance between the roots of the horns and the beginning of } \\
\text { the withers }\end{array}$ \\
\hline Frontal head length & Ltf & From the beginning of the forehead to the muzzle \\
\hline Gap between the eyes & Ey & Distance between the eyes \\
\hline Length of the large ppes & Grd epis & Length of the large ppes \\
\hline Length of the large ppes & Pt epis & Length of the large ppes \\
\hline
\end{tabular}

For the physico-chemical analysis, $100 \mathrm{~g}$ of fresh meat from two healthy individuals was used, collected cleanly in sterile sachets and placed in a cold cooler at $4^{\circ} \mathrm{C}$ and sent to the analysis laboratory. The manipulation in the laboratory is done within 24 hours after the bleeding of the animals. The preparation and analysis of the sample was done in the laboratory according to the protocol cited in the appendix 2

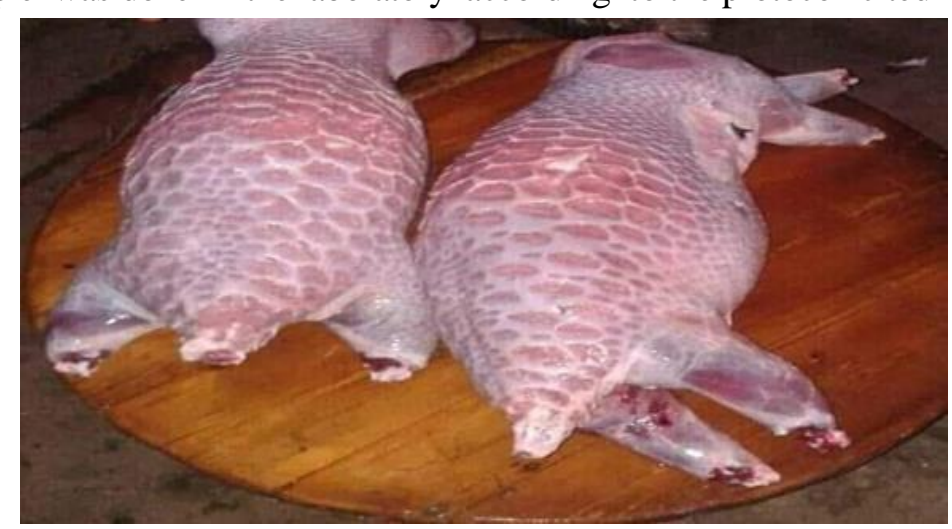

Figure 4: individuals sampled (male and female) after bleeding (Original 2019)

\section{Results}

\section{Field prospecting}

In the field, all of the people (farmers and hunters) interviewed were men between the ages of 20 and 40 . Farmers set traps for animals (Figure 5) as animals are considered pests of agricultural fields. According to our survey to farmers this animal attacks mainly the fields of potatoes, pepper, pumpkin, turnip and cucumber. However it is noticed by these farmers that the porcupine does not cause damage on the fields of tomato, watermelon, pepper sting.

Porcupine hunters were more difficult to apprehend than farmers because Algerian legislation prohibits the hunting of this animal. Hunters were at $60 \%$ traders, the rest were officials in different areas. The main cause of the porcupine's hunt was for its tasty and beneficial meat (according to the people questioned its meat is used to treat diabetics, and the stomach of the porcupine is used in traditional therapy against stomach cancer) (Figure 6). According to several people interviewed they hunt this animal for pleasure. All hunters hunt porcupine during the night (because this animal is nocturnal) and this with the help of specialized dogs trained from a young age in hunting 


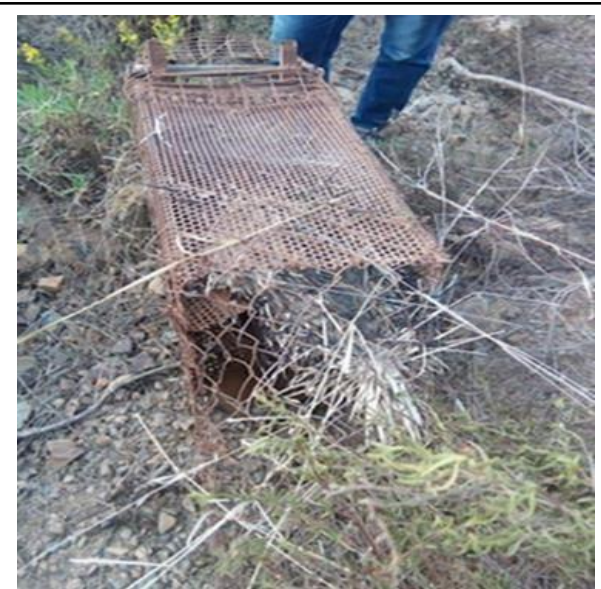

Figure 5: Cob pig trap (Maghnia, 2019)

Porcupine hunters were more difficult to apprehend than farmers because Algerian legislation prohibits the hunting of this animal. Hunters were at $60 \%$ traders, the rest were officials in different areas. The main cause of the porcupine's hunt was for its tasty and beneficial meat (according to the people questioned its meat is used to treat diabetics, and the stomach of the porcupine is used in traditional therapy against stomach cancer) (Figure 6). According to several people interviewed they hunt this animal for pleasure. All hunters hunt porcupine during the night (because this animal is nocturnal) and this with the help of specialized dogs trained from a young age in hunting.

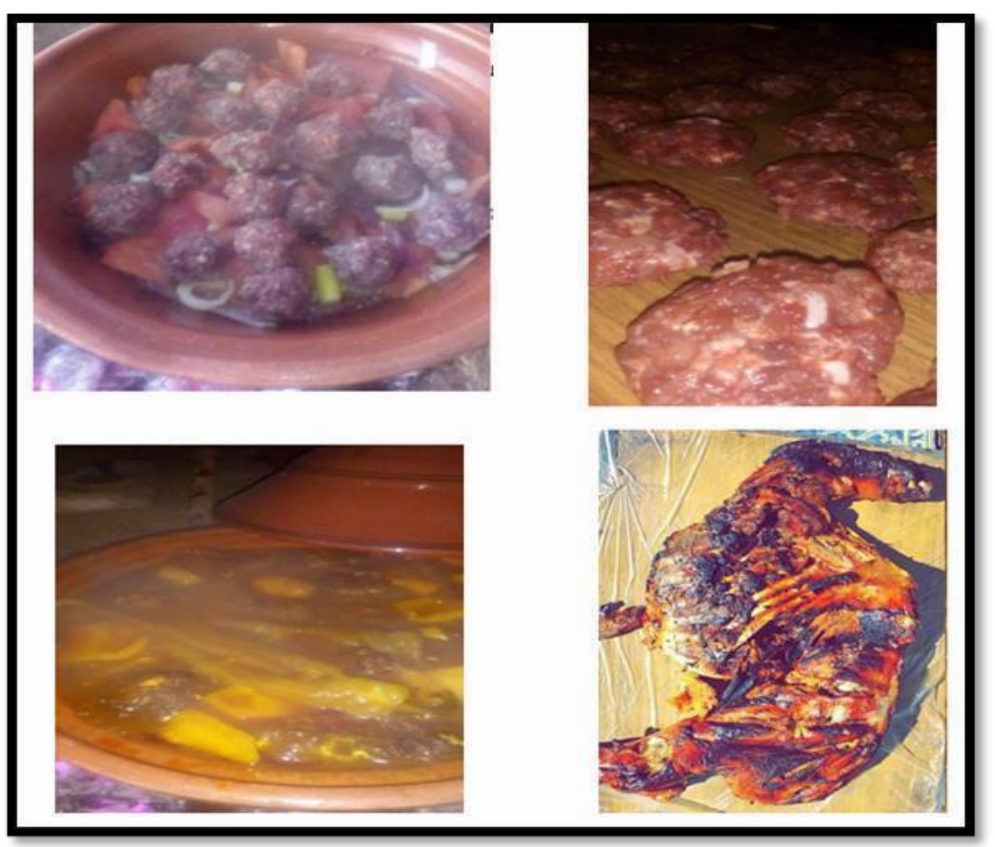

Figure 6: Photos of dishes produced with porcupine meat (hunter from the Tlemcen region, 2019)

This animal is known by its aggressiveness and according to hunters the female becomes more dangerous after low-blooding which causes injury to dogs (the lesion by the spines causes swelling and great pain). Figure 7.

Field prospecting has allowed us to value and know closely the porcupine of the Tlemcen region. Two breeds are described in this region by farmers and hunters, GHANMI and ANZI. The majority of people say that the Tlemcen region is known by the GHANMI breed (Figure 8) and the eastern Algerian regions are known by the ANZI breed (Figure 9). Hunters say that the majority of hunted individuals are dark black and dark brown, but they have also encountered light-colored animals. (Figure 10 and 11) 

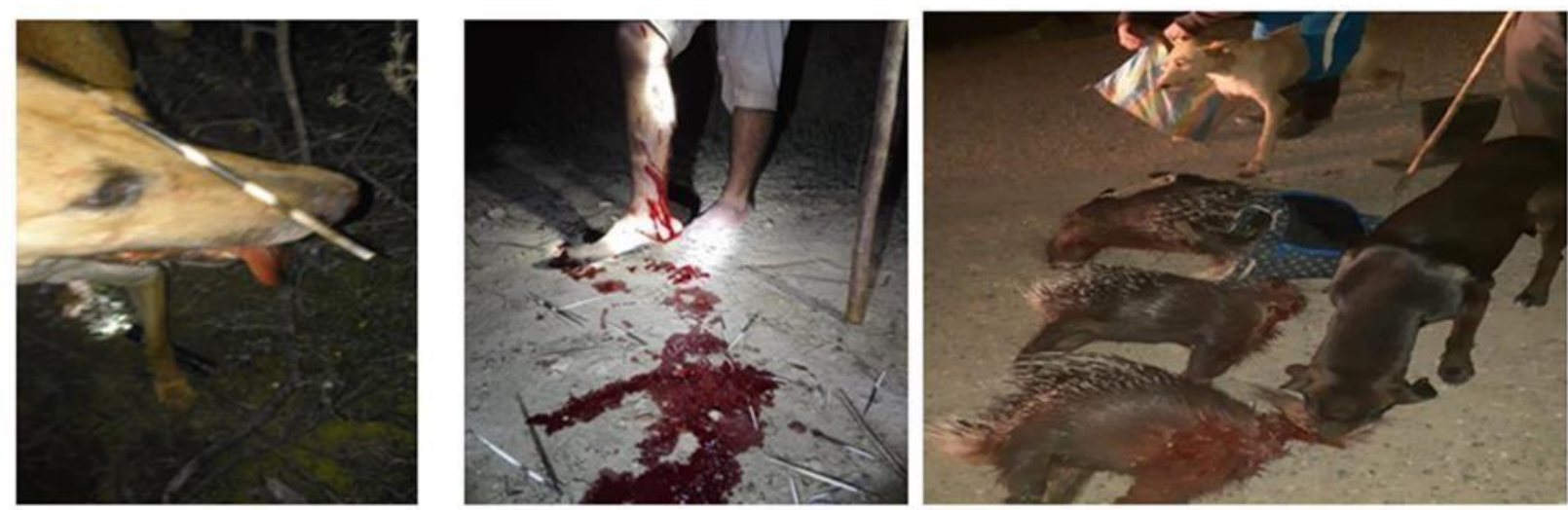

Figure 7: Damage caused by porcupine (Tlemcen Region,2018)

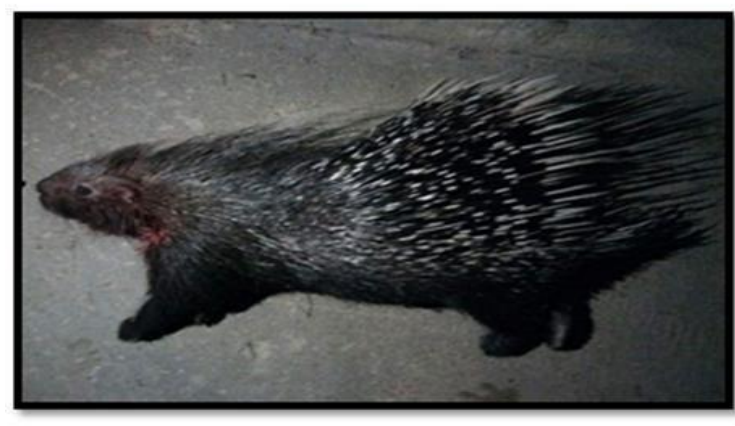

Figure 8: photo of porcupine ANZI (hunters of the Benisaf region, 2018)

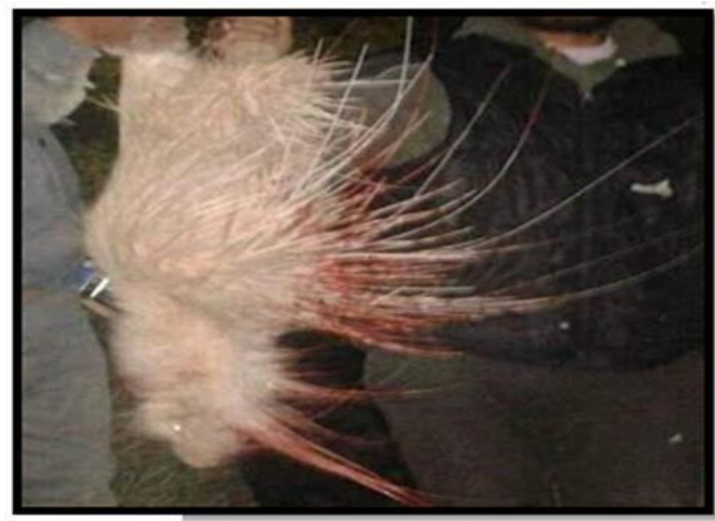

Figure 10: white porcupine photo (Maghnia area hunter, 2017)

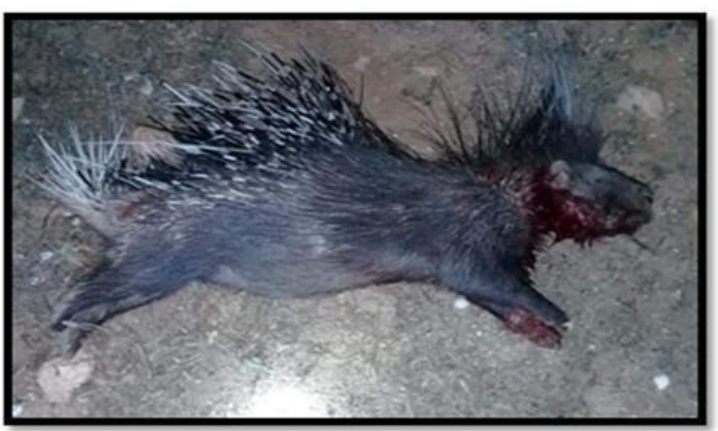

Figure 9: photo of porcupine GHANMI (Remchi ,2019)

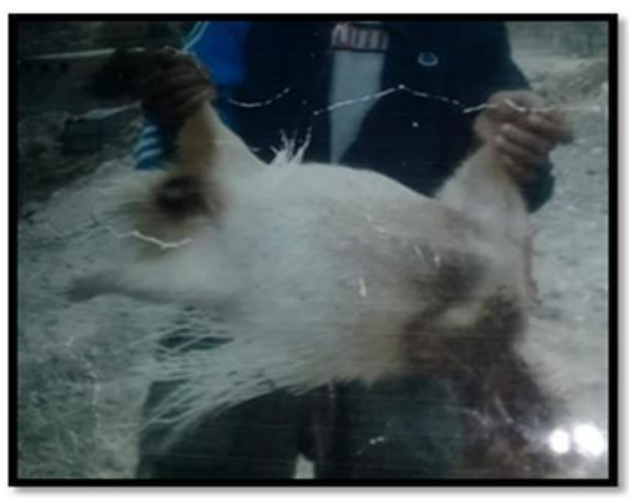

Figure 11: white porcupine photo (Benisaf Region Hunter, 2010) 


\section{Morphometric study}

Descriptive analysis

The results of the quantitative characters are reported in: arithmetic mean, standard deviation and minimum and maximum values (Table 6).

Table 6: Descriptive analysis of body measurements in the porcupine population studied.

\begin{tabular}{llllll}
\hline & Average $(\mathbf{C m})$ & Standard Error & Mèdiane $(\mathbf{C m})$ & Min $(\mathbf{C m})$ & Max $(\mathbf{C m})$ \\
\hline weight & 17.29 & 3.21 & 16.80 & 12.5 & 24.5 \\
\hline Grd.epis & 44.76 & 5.99 & 45.50 & 36.0 & 55.0 \\
\hline Pt.Epis & 2.16 & 0.71 & 1.90 & 1.3 & 3.6 \\
\hline $\mathrm{lcp}$ & 44.30 & 6.55 & 42.50 & 36.5 & 60.0 \\
\hline $\mathrm{hg}$ & 34.70 & 3.94 & 34.50 & 28.0 & 42.0 \\
\hline $\mathrm{Tp}$ & 80.73 & 15.59 & 84.50 & 57.0 & 115.0 \\
\hline $\mathrm{tca}$ & 17.80 & 0.54 & 17.60 & 17.0 & 19.0 \\
\hline $\mathrm{Tq}$ & 17.86 & 0.54 & 17.70 & 17.0 & 19.0 \\
\hline $\mathrm{tl}$ & 32.16 & 3.32 & 31.25 & 27.0 & 40.0 \\
\hline $\mathrm{Ilf}$ & 18.53 & 2.31 & 17.70 & 15.8 & 24.0 \\
\hline Inf & 19.36 & 0.36 & 19.40 & 18.6 & 20.0 \\
\hline Ey & 11.41 & 0.28 & 11.40 & 11.0 & 12.0 \\
\hline
\end{tabular}

LCp: Body length, HG: Height at withers, HS:Height at sacrum, TP: Chest circumference, TCA, Anterior barrel circumference, LQ: Tail length, TL: Neckline length, LLF:Front neckline length, LTF: Frontal head length, EY:Gap between the eyes, Grd epis:Large epi length, Pt epis: Largeepis length

For skin color (Figure 12) the data are represented as a percentage as suis: $59.09 \%$ black, $36.36 \%$ dark brown and $4.54 \%$ light brown. (Table 7)

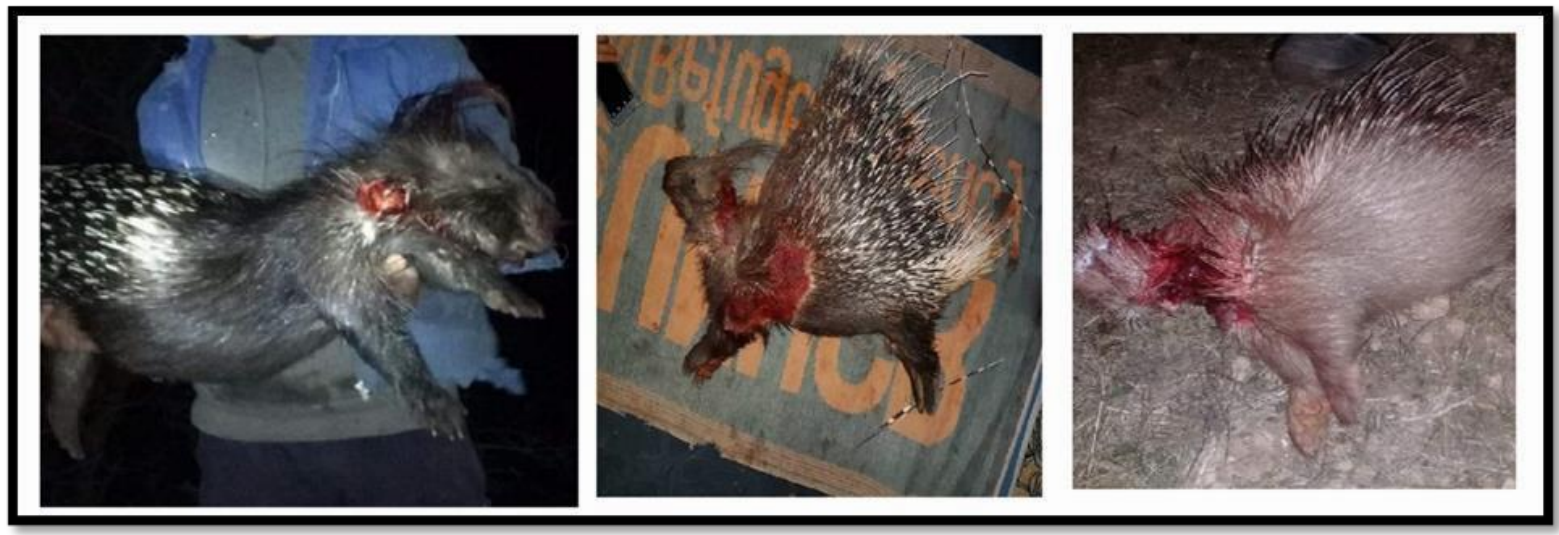

Figure 12: the different results of porcupine colors found in the region of Tlemcen (Original, 2019)

Table7: Results of the qualitative characteristics of the individuals studied

\begin{tabular}{lll}
\hline The color of the skin & Number of individuals & Percentages \% \\
\hline Dark brown & 8 & 36.36 \\
\hline black & 13 & 59.09 \\
\hline Light brown & 1 & 4.54 \\
\hline total & 22 & 100 \\
\hline
\end{tabular}

The graphical interpretation of the PCA's results is carried out mainly according to plan 1-2 (Table 08) (95.20\% contribution for axis 1 and $1.84 \%$ for axis 2 ). Which is very interesting statistically.

Principal component analysis (PCA) of the body measurements variables in porcupine (with the value $\alpha$ set at 0.05 ) allowed their distributions as shown in Figure 13. 
Table 8: The percentages of i iformation represented by the selected dimensions

\begin{tabular}{lll}
\hline & Sun.1 & Sun.2 \\
\hline variance & 11.42 & 0.22 \\
\hline Percentage of variance & 95.20 & 1.84 \\
\hline Cumulative percentages & 95.20 & 97.05 \\
\hline
\end{tabular}

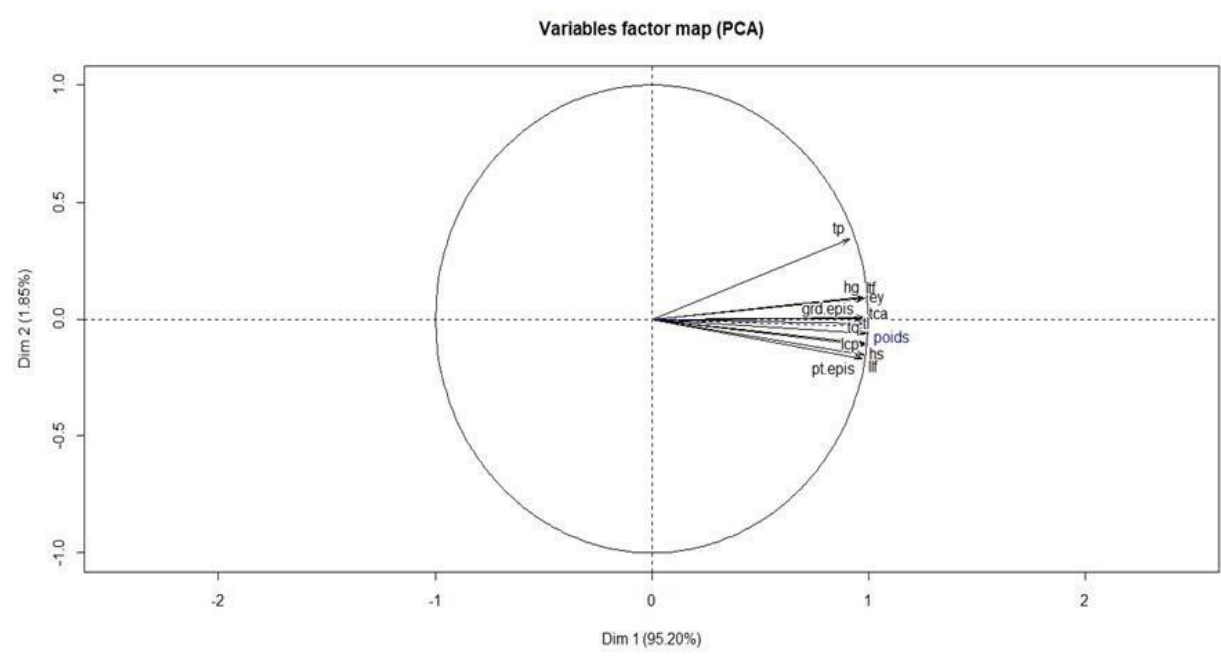

Figure 13: PCA correlation circle of study variables.

Figure 13 shows the correlation circle of the variables and shows that the variables are positively correlated and are grouped into a single group. Thus no negative correlation is observed.

The observed results show that the variables are close to the periphery of the circle and therefore expresses statistically correct results. The grouping of these traits can be explained by the fact that these traits are under the probable influence of the same group of genes globally.

\section{Variation of variables}

In order to identify in relation to that factors our sampled animals can be individualized, we began an analysis of the data by fixing the region, sex, and skin color.

\section{Variation by region}

Table 9 shows the body measurements in the porc-epic at the level of 5 different regions: Maghnia, Ghazawat, Remchi, Ain Fezza and Mafrouche in the wilaya of Tlemcen. (Table 9).

Table 9: variation of variables by region

\begin{tabular}{lll}
\hline Variables & P-value & Significance (P) \\
\hline weight & 0.028 & $*$ \\
\hline Grd.epis & 0.008 & $* *$ \\
\hline Pt.Epis & 0.067 & $\mathrm{Ns}$ \\
\hline $\mathrm{lcp}$ & 0.025 & $*$ \\
\hline $\mathrm{hg}$ & 0.028 & $*$ \\
\hline $\mathrm{Broken}$ & 0.060 & $\mathrm{Ns}$ \\
\hline $\mathrm{Tp}$ & 0.097 & $\mathrm{Ns}$ \\
\hline $\mathrm{tca}$ & 0.041 & $*$ \\
\hline $\mathrm{Tq}$ & 0.057 & $\mathrm{Ns}$ \\
\hline $\mathrm{tl}$ & 0.027 & $*$ \\
\hline $\mathrm{Llf}$ & 0.039 & $*$ \\
\hline $\mathrm{Ltf}$ & 0.018 & $*$ \\
\hline Ey & 0.010 & $* *$ \\
\hline LCp: Body length, HG: Height at withers, HS:Height at sacrum, TP: Chest circumference, TCA, Anterior barrel circumference, \\
LQ: Tail length, TL: Neckline length, LLF:Front neckline length, LTF: Frontal head length, EY:Gap between the eyes, Grd \\
epis:Large epi length, Pt epis: Largeepis length, * $p<0.05$ significant, $* *: p<0.01$ very significant, Ns: not significant
\end{tabular}


The results show that there is a significant variation $(\mathrm{p}<0.005)$ depending on the region for the characters: Weight, length of the large spike, length of the body (Lcp), height at the withers ( $\mathrm{Hg})$, turn of the anterior barrel (Tca), turn of the neckline (Tl), length of the frontal neckline (Llf), length of the frontal head (Ltf), gap between the eyes (Ey) for the variables that remain, there are no significant differences between the variables $(\mathrm{p}>0.05)$.

Principal component analysis of individuals by region shows that:

- The majority of individuals in the inner solid areas have important values. This is the case of animals in the maghnia and remchiregion.

- The majority of individuals in forested areas carry low values. This is the case of animals in the region of Ghazawat, Mafrouche and Ain Fezza.

- Animals in the Ain Fezza region and those in the Ghazawat region appear to be more homogeneous and grouping than other animals in other regions.

This difference in performance between animals of the open interior and forest and may be due to a form of adaptation to the climate, diet and environment but also has genetic differences. The regrouping of animals from the Ain Fezza regions and those from the Ghazawat region is probably due to the isolation of these two populations.

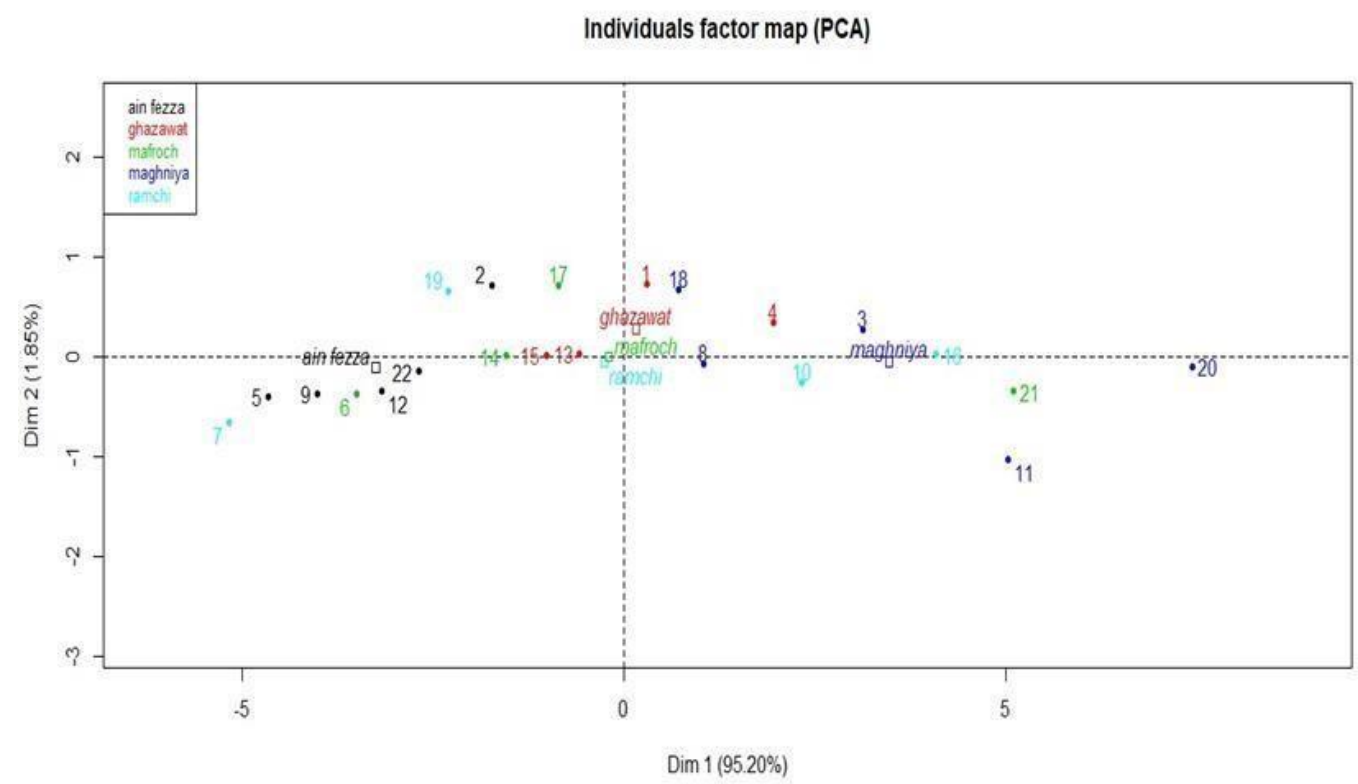

Figure14: Analysis of principal components (distribution of individuals by region)

\section{Variations by sex}

Table 10 presents body measurements in porcupine by sex in the study area. The results show that there is a significant variation $(\mathrm{p}<0.005)$ by sex for the characters: Weight, height at the withers $(\mathrm{Hg})$, height at the sacrum (Hs), turn of the anterior barrel(Tca), length of the tail (Lq), turn of the neckline (Tl), length of the frontal head (Ltf) and gap between the eyes (Ey).

For the remaining variables there are no significant differences between the two sexes $(p>0.05)$.

Principal component analysis of individuals by sex shows that the animals are fairly homogeneous and that sexual dimorphism is not very apparent (Figure 15).

\section{Variations by skin color}

From statistical analyses of body measurements in porcupine by skin colour in the Tlemcen region it is clear that there are no significant differences ( $p>0.05$ ) for any traits studied (Table 11). 
Table10: Variation of variables by sex

\begin{tabular}{l|l|l}
\hline Variables & P-Value & Significance (P) \\
\hline weight & 0.037 & $*$ \\
\hline Grd.epis & 0.062 & Ns \\
\hline Pt.epis & 0.062 & Ns \\
\hline lcp & 0.054 & Ns \\
\hline hg & 0.021 & $*$ \\
\hline Broken & 0.041 & $*$ \\
\hline Tp & 1.93 & Ns \\
\hline tca & 0.023 & $*$ \\
\hline Tq & 0.023 & $*$ \\
\hline tl & 0.043 & $*$ \\
\hline Llf & 0.073 & Ns \\
\hline Ey & 0.033 & $*$ \\
\hline
\end{tabular}

LCp: Body length, HG: Height at withers, HS:Height at sacrum, TP: Chest circumference, TCA, Anterior barrel circumference, LQ: Tail length, TL: Neckline length, LLF:Front neckline length, LTF: Frontal head length, EY:Gap between the eyes, Grd epis:Large ppes length, Pt epis: Large ppeslength $/ *: p<0.05$ significant, Ns: not significant

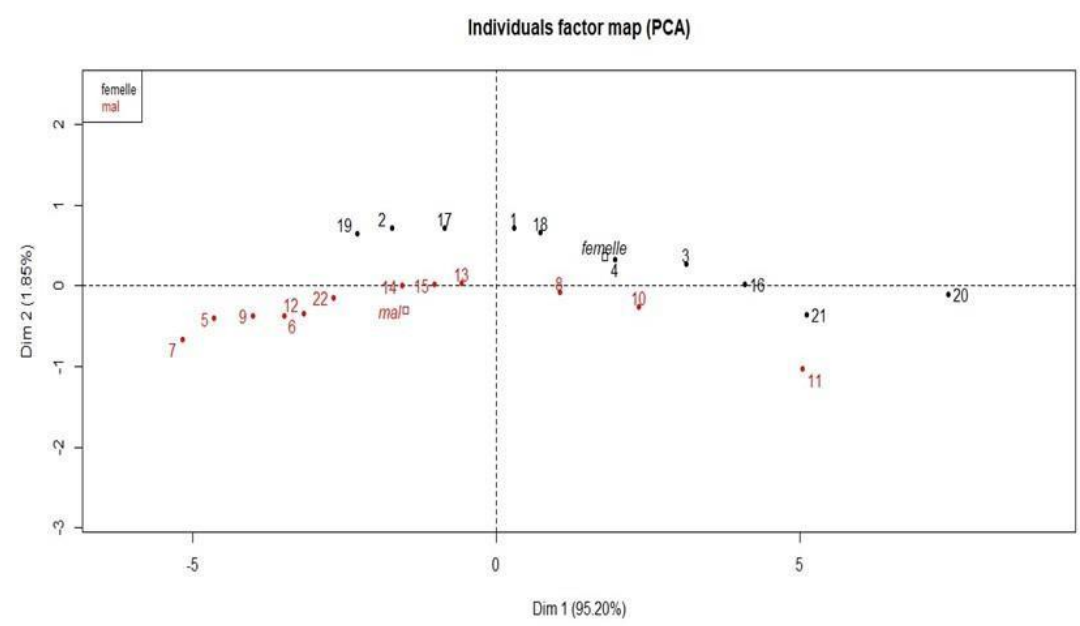

Figure 15: Analysis of major components (distribution of individuals by sex)

Table 11: variation of variables according to skin colour

\begin{tabular}{lll}
\hline Variables & P-value & Significance. (P) \\
\hline weight & 0.319 & Ns \\
\hline Grd.epis & 0.315 & Ns \\
\hline Pt.epis & 0.340 & Ns \\
\hline lcp & 0.382 & Ns \\
\hline hg & 0.278 & Ns \\
\hline Broken & 0.372 & Ns \\
\hline Tp & 0.281 & Ns \\
\hline tca & 0.347 & Ns \\
\hline Tq & 0.321 & Ns \\
\hline tl & 0.340 & Ns \\
\hline Llf & 0.365 & Ns \\
\hline Ltf & 0.309 & Ns \\
\hline Ey & 0.181 & Ns \\
\hline
\end{tabular}

LCp: Body length, HG: Height at withers, HS:Height at sacrum, TP: Chest circumference, TCA, Anterior barrel circumference, LQ: Tail length, TL: Neckline length, LLF:Front neckline length, LTF: Frontal head length, EY:Gap between the eyes, Grd epis:Large ppes length, Pt epis: Large ppeslength, Ns: significant not significant 
Principal component analysis of individuals by skin colour and distribution shows no difference between individuals (Figure 16).

\section{Hierarchical Bottom-up Classification (HAC)}

The hierarchical bottom-up classification (HFA) (Figure 16) of our sample reflects the same results expressed by the principal component analysis of individuals and it distinguished four (4) classes (Figure 18).

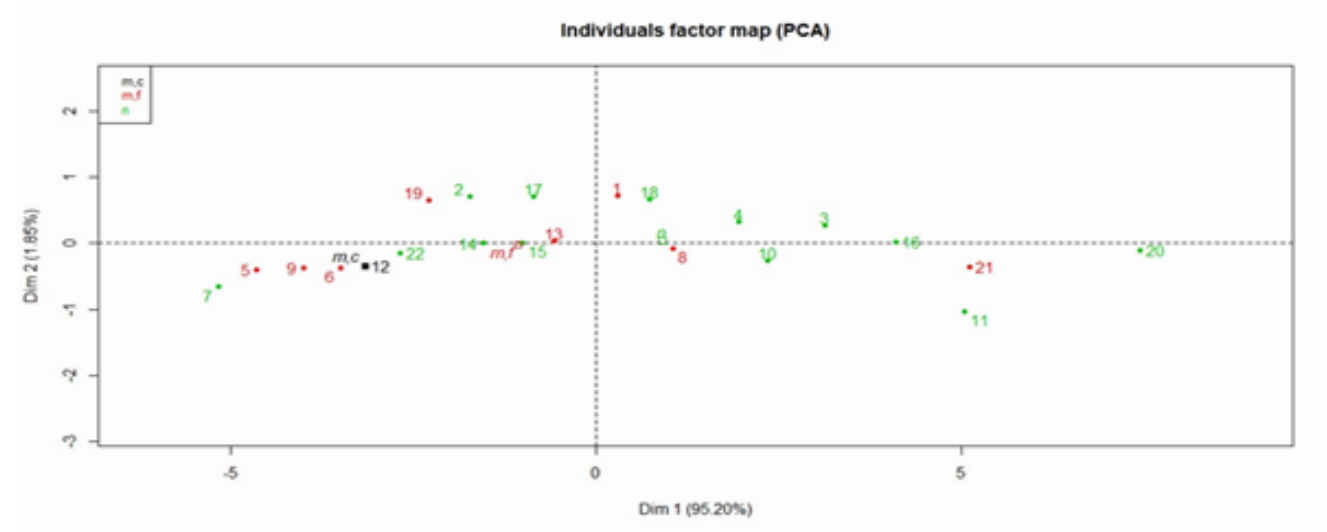

Figure16: Principal component analysis (distribution of individuals by skin colour)

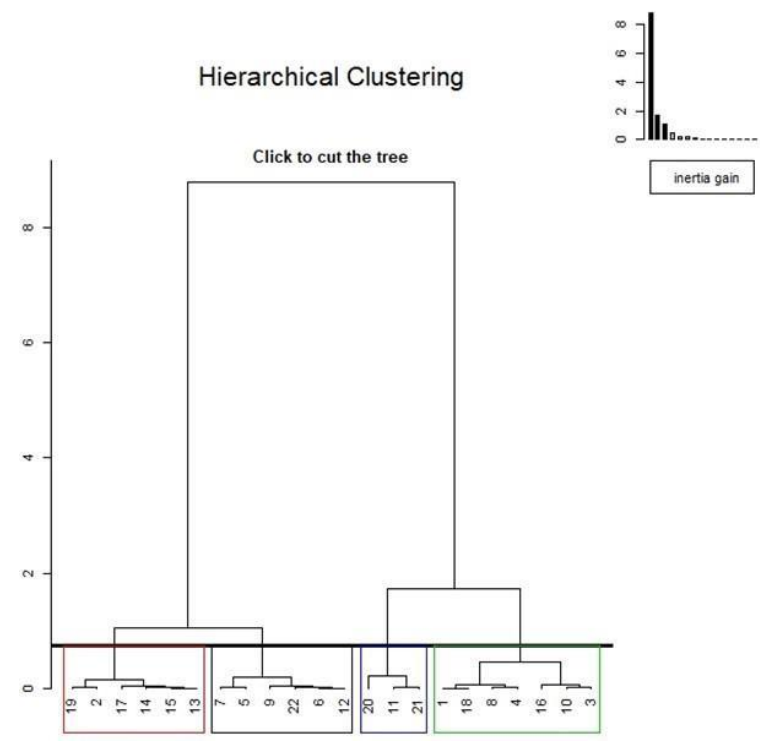

Figure17: Dendrogram of hierarchical ascending classification

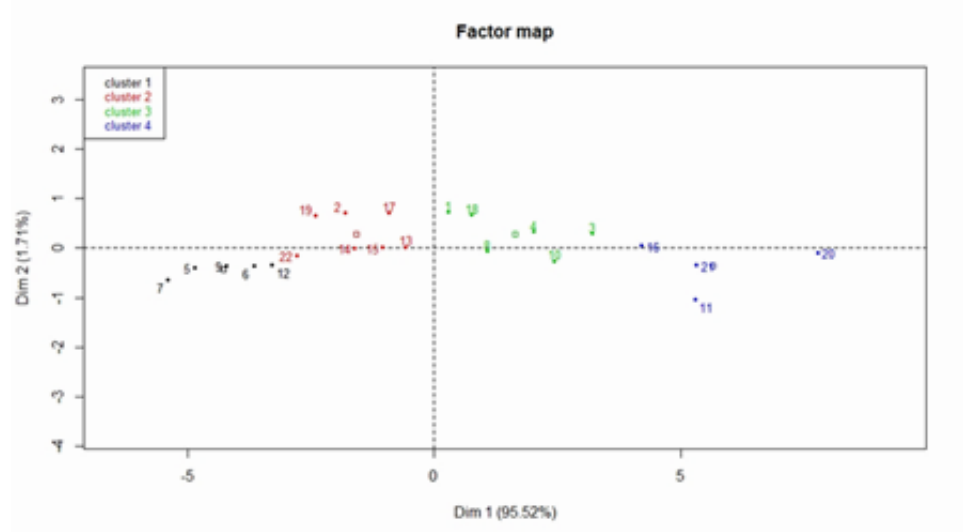

Figure18: Principal Component Analysis by Class 
Cluster 1 in black group individuals who have low values for the characters studied..We detecte that the majority of individuals are from forested areas like a region of Ghazawat, Mafrouche and Ain Fezza.

Cluster 2 in red and cluster 3 in green group animals that have average values for the characters studied. The majority of animals was from Ain Fezza region and those of Ghazaouet region.

Cluster 4 in blue group together the individuals who have the most important values for the characters studied. We observe that the majority of individuals was from maghnia and remchi region.

The Dendrogram of hierarchical ascending classification of our sample reflects the same results expressed by the principal component analysis of individuals by region.

\section{Distance de Mahalanobis}

All morphometric analyses revealed the existence of morphologically differentiated (4 groupes). The Mahalanobis distance of all variables is not large and this means that the variables correspond to the standards of the data set. (Figure 19 and 20)

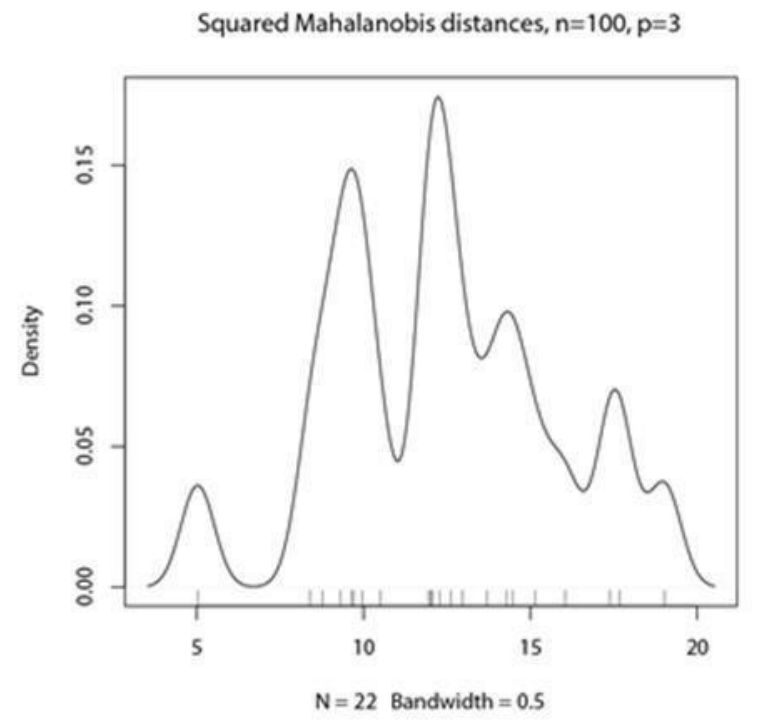

Figure 19: distance from Mahalanobis to squared

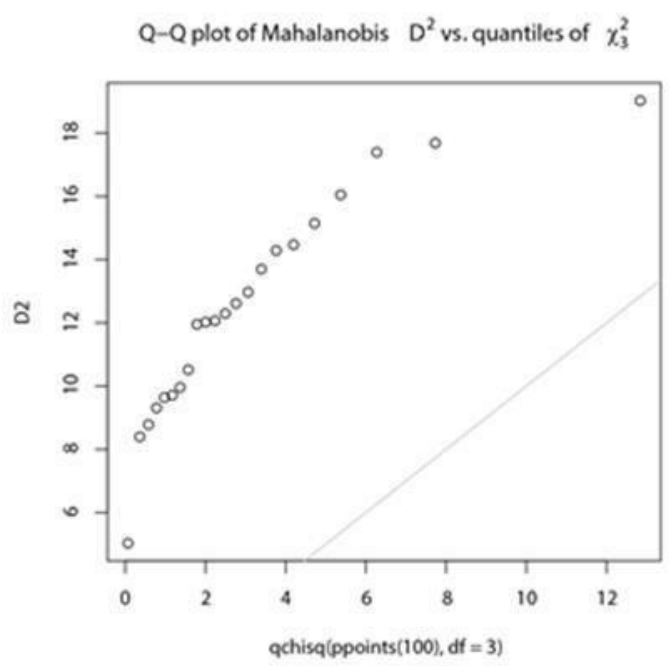

Figure 20: Quantile-Quantile Diagram

The dendrogram of the Mahalanobis distance (Figure 21) of our sample made it possible to distinguish four (4) classes based on the different body measurements carried out during our experiment and confirms the previous analyses.

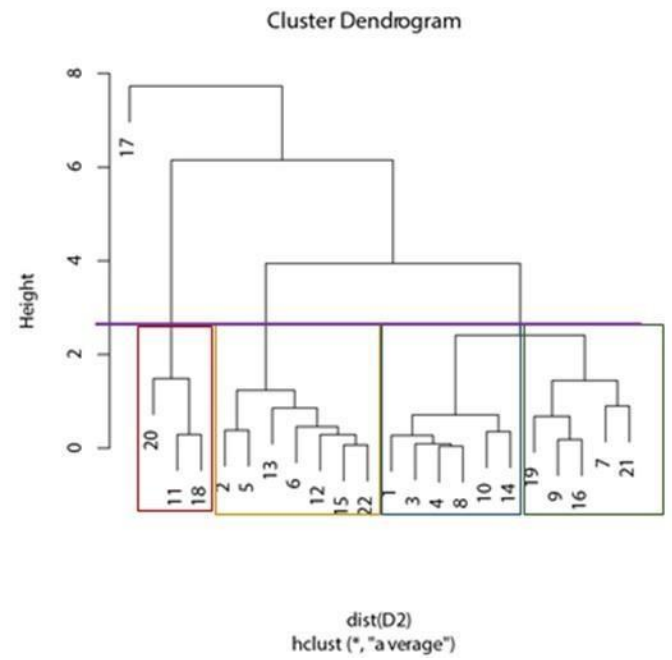

Figure 21: Dendrogram of mahalanobis distance 


\section{Physico-chemical analysis of meat}

The results of physico-chemical analysis of the meat (100g of fresh meat) of the 2 individuals (male and female) of the Ghanmi breed are cited in Tables 12 (for the male) and 13 (for the female).

The analysis of the carbohydrate content and energy value of carbohydrates for $100 \mathrm{~g}$ of meat was negative that shows that porcupine meat is low in carbohydrates. On the other hand the protein content is $20-21.5 \mathrm{~g}$ per $100 \mathrm{~g}$ respectively for the female and the male. On the other hand, the lipid content is quite important in the female by contribution that of the male ( $3 \mathrm{~g}$ in the female and $1.35 \mathrm{~g}$ in the male).

Table12: Result of the analysis of "male" porcupine meat

\begin{tabular}{ll}
\hline Parameters & Result \\
\hline Lipid content & $1.35 \mathrm{~g}$ \\
\hline Energy value of lipids & $12.15 \mathrm{~K} \mathrm{cal}-49.95 \mathrm{~K}$ joules \\
\hline Protein content & $21.53 \mathrm{~g}$ \\
\hline Energy value of proteins & $86.12 \mathrm{~K} \mathrm{cal}-360 \mathrm{~K}$ joules \\
\hline Carbohydrate content & $00 \mathrm{~g}$ \\
\hline Energy value of carbohydrates & $00 \mathrm{~K} \mathrm{cal}-00 \mathrm{~K}$ joules \\
\hline Total energy value & $98.27 \mathrm{~K} \mathrm{cals}-410 \mathrm{~K}$ joules \\
\hline
\end{tabular}

Table13:Result of the analysis of "female" porcupine meat

\begin{tabular}{ll}
\hline Parameters & Results \\
\hline Lipid content on $100 \mathrm{~g}$ product & $3 \mathrm{~g}$ \\
\hline Energy value of lipids on $100 \mathrm{~g}$ of product & $27 \mathrm{~K} \mathrm{cal}-111 \mathrm{~K}$ joules \\
\hline Protein content on $100 \mathrm{~g}$ product & $20 \mathrm{~g}$ \\
\hline Energy value of proteins on $100 \mathrm{~g}$ of product & $80 \mathrm{~K} \mathrm{cal}-340 \mathrm{~K}$ joules \\
\hline Carbohydrate content on $100 \mathrm{~g}$ of product & $00 \mathrm{~g}$ \\
\hline Energy value of carbohydrates on $100 \mathrm{~g}$ of product & $00 \mathrm{~K} \mathrm{cal}-00 \mathrm{~K}$ joules \\
\hline Total energy value on $100 \mathrm{~g}$ of product & $107 \mathrm{~K}$ cals $-451 \mathrm{~K}$ joules \\
\hline
\end{tabular}

If we compare our results with rabbit meat (Orictolagus cuniculus), chicken (Gallus gallus domesticus), and calf taurillon (Bostaurus) for 100g described by Ciquale, 2008 and Combes, 2004; Salvini et al., 1998 it is noted that the protein content in rabbits and calf is close to that of male porcupine. For chickens and taurillons the protein content is less important than that of the male porcupine but is a little closer to the values of that of the female. If we compare the lipid content in chicken, veal, taurillon and rabbit these values are important compared to that reported at the level of the meat of the male and the female porcupine. On the other hand, the carbohydrate content in rabbits described by Ciquale, 2008 is $0.5 \mathrm{~g} / 100 \mathrm{~g}$ of meat while in porcupine carbohydrates are non-existent. The total energy value per $100 \mathrm{~g}$ of rabbit meat is $167 \mathrm{kcal}$ while it is $98.27-107 \mathrm{Kcal}$ in porcupine.

\section{Conclusion}

In the present study, we addressed the agro-ecological, phenotypic, physico-chemical aspect of cob pigs (Hystrix cristata)in the wilaya Tlemcen. Field surveys have begun to gain knowledge of this species in terms of its way of life, diet, habitat and distribution, characteristics and importance in the Tlemcen region. 22 adult porcupines were sampled: 10 females and 12 male in 5 different areas (Maghnia, Mafrouche, Ain Fezza, Ghazawat and Remchi) of the wilaya of Tlemcen. The morpho metric study is based on 13 quantitative variables and 3 qualitative variables; this approach was carried out by the descriptive analysis of the variables and a study of the correlations between the quantitative variables, followed by an analysis in main component and finally a hierarchical bottom-up classification. Descriptive analysis revealed that females have a greater build than males; the black color of the skin $(59.09 \%)$ is the most dominant compared to the dark brown color $(36.36 \%)$ and light brown (4.54\%). The principal component analysis (PCA) showed that all quantitative variables are positively correlated with each other. The main component analysis of individuals by region shows that the majority of individuals in the interior plains have important values (Maghnia and Remchi) and the majority of individuals in forest areas have the lowest values (Ghazawat, Mafrouche and Ain fezza). Principal component analysis of individuals by sex shows that females contain high values by intake to males. Principal component analysis of individuals by skin color shows no difference between individuals. The hierarchical bottom-up classification $(\mathrm{CAH})$ confirmed the results of the 
CPA which allowed us to distinguish 4 classes. The results of physico-chemical analysis of the fresh meat of the 2 individuals (male and female) of the Ghanmi breed, per 100g of fresh meat reveal that the protein content is $21.5-20 \mathrm{~g}$, the lipid content is quite important in the female by intake to the male ( $3 \mathrm{~g}$ in female and $1.35 \mathrm{~g}$ in the male). On the other hand, the carbohydrate content and for $100 \mathrm{~g}$ of meat was zero.

\section{References}

Adamou-Djerbaoui MC. Denys C. Chaba H. Seid MM. Djelaila Y. La B Delli F. ADAM Ou MS. 2012 . Study of the diet of a harmful rodent (Meriones shawii, duvernoy, 1842). Mammalia, rodentia in Algeria. Lebanese Science Journal, Vol. 14, No. 1, 15-32.

Abdelguerfi Chehat F. Ferrah A. Yahiaoui S 2009. National Report on Biodiversity Conservation and Ecosystem Resilience: Opportunities for Agricultural Development and Growth in Algeria

Banfield AWF. 1977. Les mammifères du Canada, 2nd ed., Presses de l'Université Laval and University of Toronto Press, pp. 216-219.

Combes S. 2004. Nutritional value of rabbit meat: A review. Animal Productions -Paris- Institut National de la Recherche Agronomique- 17(5):373-383

Ciquale. 2008. Tmeat eneur site https://ciqual.anses.fr/

Efrem AF. Antonella C. and Alberigo N 2016. Infection with encephalomyyocarditis virus in Macaca sylvanus and Hystrix cristata in an Italian rescue center for wild and exotic animals

Giusy C. Valeria M. Claudia E. Marco A. Goffredo G. Stefania S. Giampiero D. Valeria A. 2016. Encephalomyocarditis virus infection in Macaca sylvanus and Hystrix cristata from an Italian rescue centre for wild and exotic animals, doi: 10.1186/s12985-016-0653-9

Gouat P. And Gouat J. 1982. The distribution of Goundi (Ctenodactylus gundi, Rothman 1776) in the Aurès massif (Algeria). C. R. Acad. Sc. Paris, seér III. 294:50 1-503.

Gouat P. And Gouat J. 1983. The habitat of the goundi (Ctenodactylus gundi, Rothman1776) in the Massif de l'Aurès (Algeria). Mammalia. 47: 507-518.

Gouat J. 1985. Notes on the reproduction of Ctenodactylus gundi (Ctenodactylus gundi, Rothman1776) rodent Ctenodactylidae. Z.Saugetierkunde. 50: 285-293.

Gouat P. And Gouat J. 1987. Le répertoire comportemental du goundi,(Ctenodactylus gundi, Rothman1776). Mammalia. 51: 3-25.

Gouat P. 1988. Socioecological study of three species of rodents Ctenographeds of A lgérie. Doctoral thesis. U niversity of Lyon 1.311

Karaouzen. quality analysis laboratory approve (maintenance and cosmetic agro-food products approved by ministerial decision No. 26 of 17-10-2017).

Koenen FH. Vanderhallen ND. Dickinson NJ. Knowles 1999. Phylogenetic analysis of European encephalomyocarditis viruses: comparison of two genomic regions.

Myers N. Mittermeier RA. Mittermeier CG. Da Fonseca GAB. Kent J. et al, 2000. Biodiversity hotspot for conservation priorities Nature volume 403, pages853-858 (2000)

Olson DM. Dinerstein E. Wikramanayake ED. et al., 2001. Terrestrial Ecoregions of the World: A New Map of Life on Earth. A new global map of terrestrial ecoregions provides an innovative tool for conserving biodiversity BioScience 51 (11), Nov 2001: 933-938

Sandro L. Maria T. Corsini B. Guazzini G. Romeo EM. 2017. Suburban ecology of crested porcupine in a heavily poached region: a global approach. European Journal of Wildlife Research, vol 63:10

Stork N. Samways MJ. Bryant DA et al. 1995. Inventorying and monitoring of biodiversity;

Yaa Ntiamoa-Baidu, 1987 The fauna of West Africa: An endangered natural resource. International Review of Forests and Forest Industries - Vol. 39 - 1987/2 